\title{
Intangible Cultural Heritage in architecture and urban planning
}

\author{
Neel Kamal Chapagain
}

For citation: Chapagain, Neel Kamal. 2020. Intangible Cultural Heritage in architecture and urban planning. Pravovedenie 64 (1): 35-46. https://doi.org/10.21638/spbu25.2020.103

\begin{abstract}
This article reflects several observations of our cities during the COVID-19 pandemic - particularly the initial lockdown that most parts of the world experienced since March 2020. One of the impacts of COVID-19 has been the forced closeness of people with their homes wherever they were. In the present age, perhaps, many of us have rarely experienced our own homes or shelters or architecture so closely. The pandemic may have brought us an extended moment to experience and reflect on architecture and urban planning on a very personal scale - from a room, to an apartment or a house, a neighbourhood, and then perhaps a city on a limited scale. This is an interesting moment in history to reflect on architecture and space, and how they are designed and planned. COVID-19 has exposed the limitations of many of our thoughts and practices. Apart from the author's own self-reflections at "home", observations include the context of South Asian cities where the globally accepted measure of lockdown to prevent the spread of COVID-19 triggered the plight of millions of migrants on the momentarily empty roads and highways for a long-march towards rural and semi-urban segments of countries. This led to the author's re-thinking of architecture and planning in urban contexts. In (re)thinking architecture and urban planning, the article uses the notion of intangible cultural heritage (ICH) as espoused by the 2003 UNESCO Convention, and discusses whether ICH could offer useful insights to achieve better results in our contemporary architecture and urban planning thinking and practice. Can the $\mathrm{ICH}$ perspective help us to understand these bitter realities of the $21^{\text {st }}$ century? The author attempts to reflect on some of the questions.
\end{abstract}

Keywords: COVID-19, intangible cultural heritage, Kathmandu Valley, world heritage, architecture and urban planning, UNESCO.

One of the impacts of COVID-19 has been the forced closeness of people with their homes wherever they are. In the current era, perhaps many of us have rarely experienced our own homes or shelters or architecture that closely. So, the pandemic may have brought us an extended moment to experience and reflect on architecture and urban planning at a very personal scale - from a room, to an apartment or a house, to a neighbourhood, then perhaps a city in limited ways. This is an interesting moment in history to reflect on the architecture and space, and how they are designed and planned. It is within the world of this close architecture and urban planning that we might have been traversing between the real and virtual, tangible and intangible, natural and cultural, and so on. Though this is (was) momentary until the lockdown and other COVID-19 restrictions are in place, personally I find it a unique historical moment to reflect on our personal space, family space, the home and the neighbourhood. This is the experience of the privileged group. But there are also other groups - not so privileged or less privileged, unprivileged or those for whom any situation seem the same.

Neel Kamal Chapagain - PhD, Independent Architect and Heritage Professional, Nepal, Associate Professor \& Director, Centre for Heritage Management, Ahmedabad University, Commerce Six Roads, Ahmedabad, Navrangpura, Gujarat, 380009, India; neel.kamal@ahduni.edu.in

(c) St. Petersburg State University, 2021 
Unfortunately, there has also been a very painful experience (for other who do not fit into what I termed privileged in the last paragraph) in many cities in South Asia, where the consequences of urban response to COVID-19 has resulted in a struggle between "home" and "work" for millions of migrants. As the pandemic forced governments to announce stay home orders, this unprivileged group was perplexed by the notion of "home" and the act of "staying". "Home" can be defined in multiple ways, in connection with the basic rights of being human, feeling close to where one belongs, a place or refuge where one can feel safe and comfortable, and as the popular saying goes "home is where heart is". In other words, a home is a concept, a space, a structure that gives solace to people. Our cities are called "home" by many people - residents, nonresidents alike. Differing classes of working people call the same city as home, within which they would have found a range of spaces that they would call home. There would be infrastructures laid around to ensure that all kinds of workers are secured in the city where they work, as their home. Of course, people would have multiple homes, which are free for them to navigate between. However, these all came to a completely different interpretation as the pandemic began to take its toll and the governments in South Asia took proactive measures to declare a complete lockdown in March 2020. As I followed strictly the "stay home" orders in the comfort of place and structure I call home, I realised it was very timely for us to reflect on the idea of architecture and urban planning, and reflect into their deeper meaning beyond the physical buildings and infrastructures. This is where perhaps the idea of intangible cultural heritage helps to examine the unseen features of our architecture and urban planning.

\section{Observations during the COVID-19 lockdown in Nepal and India}

As the world came to a standstill in a relatively shorter span of time in the first quarter of 2020, we experienced a different world through our windows - sounds of birds, sometimes noticing different species of birds and other species, seeing clearer skies, and so on. People of Kathmandu valley in Nepal witnessed a historic unprecedented scene - to be able to see extensively beautiful and clear panorama of the Himalayan mountain range, including a published picture by a journalist where he could even point out the Mt Everest $^{1}$. This was beyond the imagination of many generations in Kathmandu I think. Staying at home, I was able to observe for myself the cycles of flowering and fruiting in some of the plants in the kitchen garden, slow motion video recordings of insects' movements and so on. Our son celebrated his tenth birthday away from us but creatively termed it as a digital birthday celebration and did manage well to integrate digital technologies not only to connect but also cheer up his own "locked down" situation by integrating online games to party with his friends and cousins. These all, however, are memorable experiences of the "privileged".

Unfortunately, the lockdown and stay home literally compelled many working people in our societies to come out of their temporary homes in the cities to make a move towards their "real" home. There were thousands of people taking to the streets and to the highways travelling out of the Kathmandu valley on foot because the lockdown closed down all forms of transports. This was the same and even worse scenario across India where perhaps the biggest mass migration in recent history was observed by many of us via our television sets. Though it was not officially authorised to walk on the roads, but it was the desperate choice made between the virus threat and the virtue of survival.

1 Gautam A. When the air is clean // Nepali Times. 2020. Available at: https://www.nepalitimes.com/ banner/when-the-air-is-clean (accessed: 16.05.2020). 
In Kathmandu valley, perhaps the previous panic the city had experienced was during the 2015 earthquakes. At that time, most of the physical monuments were destroyed, and subsequently were given good attention from both the national and international agencies. Such attention was possible because the Kathmandu valley has the privilege of hosting seven heritage zones listed in the World Heritage Sites list of UNESCO since the 1978. But this pandemic did not impact these heritage sites except that their visitation by tourists were interrupted - which was recognised by the government and authorities sometime later when the economic impacts of the lockdown were felt. However, the people who were impacted by the pandemic did not seem to be like any concern for the government which was so concerned about the rebuilding of physical monuments. Even when the traditional festivals (locally called jatras) had to be postponed due to the pandemic, the government in Nepal did not feel it necessary to consult the traditional practitioners and followers. They could simply impose restrictions since it would violate the "distancing" norms prescribed for the pandemic situation. Yet, the same "distancing" norm would not be referred when there would be a need of a political gathering or a meeting of the affluent. One may interpret these incidences as a matter of national politics, but I interpret these as lack of sensitivity towards the cultural heritage. What is more bothering as a dilemma for me is related to the heritage thinking that we have carried largely. On the one hand, heritage professionals keep arguing that heritage offers resilience (though not much demonstrated in practice), and on the other hand, the rest of the society seem to ignore the heritage that makes a city or home - they ignore the intangible mostly whereas the tangibles seem to receive some attention due to their physical existence. This dilemma is what I would like to reflect upon in this article.

As I focus on the intangible cultural heritage, let us remember a fundamental ground of intangible cultural heritage, that it exists in the minds and practices of people, hence it is also called living heritage. Intangibles are also not as separate to the tangibles as these are the intangibles which give meaning to the tangibles ${ }^{2}$ like cities and our homes. Therefore, the negligence of intangible heritage cannot be done without neglecting people the carrier, bearer, practitioners and beneficiaries of such intangible legacies. Evidently, the problem of separation of tangible and intangible heritage in heritage practice seems to have a much higher toll during the health related pandemic as it does not hurt the tangibles but the intangibles - hence, the people become victims in multiple ways. In countries like Nepal, where the basic rights of citizens are largely not fulfilled due to still existing socio-political injustices, it was evident that the people with less economic power are the bigger victims of the pandemic as they resorted to mass-migration out from the cities because their economic utility during a complete lockdown was very low. This inhumane scenario that I observed during the pandemic lockdown made me question - what good are our heritage sites or heritage legacies are for, if they have no relevance to people? It may sound like an extreme argument but what I would like to highlight is what we have largely missed in our heritage interpretation so far.

As a heritage educator, I wondered what good are those world heritage sites for the citizens. Well, heritage sites do not come to rescue at such crisis - one may think. That is because our interpretation of the heritage of Kathmandu valley has only been limited to the bricks and mortars, the tiered roofs and the squares, the sacred temples and some rituals. Even when we recognised the rituals and practices as being integral part of the heritage discourse, we somehow do that detached from the built space and made them an island of intangible cultural heritage. It is where we have missed to understand these heritage sites which formed our cities. It was our mistake to develop a perception of tangible

2 Smith L. Uses of heritage. London: Routledge, 2006. 
and intangible as distinct worlds of heritage, which have been decried ${ }^{3}$. Hence, I would not put the entire blame just on the politicians or the government for such an indifference adopted for its own citizens during the pandemic, but I would suggest that the heritage professionals dealing with such rich heritage sites are also partially to be blamed for missing out on deeper interpretation of the heritage of these cities.

As I discover through an article ${ }^{4}$ (written not by a heritage professional but a journalist) that appears in a newspaper soon after, that the Kathmandu valley had imagined and practiced the process of quarantine at least two centuries before 2020 pandemic. There were public rest houses where merchants returning home from business trip would spend a week, purify themselves following certain rituals, and come home only after ensuring that everything and everyone is well quarantined. All this would take place at the few entry points to the valley. Yet, this all was treated like a ceremony or ritual that one would go through voluntarily. Within the cities, there would be public rest houses for the street walkers and travellers to take rest, and occasionally they would also be fed and offered drinks at places. These all became a things of ancient past in the twenty first century when the fellow citizens walked days and days without anyone offering them food or shelter. Rather, there have been incidents where neighbours did not allow anyone coming from outside to enter the neighbourhood for the fear of the coronavirus. Anyone being diagnosed positively with coronavirus were treated as if they were no longer humans or as if they committed crime.

In this paper, I would like to reflect what relevance the idea of heritage has in such situations. More specifically, I argue that the discourses of heritage - particularly that of the Intangible Cultural Heritage $(\mathrm{ICH})^{5}$ may be a useful concept within our understanding and practice of architecture and urban planning.

\section{Response to COVID-19 and missing out on heritage aspects}

The very first response to the COVID-19 crisis in many countries was some variant of "stay home" order, with a widespread slogan of "stay home, stay safe". I would like to list here a few simple questions which require deeper reflection and retrospection of some of these basic concepts and terminologies. In doing this, I begin to explore some relationships between the idea of home and the intangible cultural heritage, and the same can be expanded to a neighbourhood and to a city.

- What is "home"?

- Does everyone have "home"?

- What is people's relationship with "home"? Why staying home has become a mental issue? (There has been reports of psychological issues and mental health issues that different age groups are facing during this crisis, particularly since people are confined at home for a longer stretch. There may be multiple areas of inquiry, i.e. whether the "home" is a contemporary space and function has missed out on individual's personal needs or aspirations, or whether the ability to move around freely is a primary factor that contemporary society is concerned with? In

${ }^{3}$ Chapagain N.K. Blurring boundaries and moving beyond the tangible/intangible and the natural/ cultural classifications of heritage: Cases from Nepal // Cultural landscapes of South Asia: Studies in heritage conservation and management / eds Amita Sinha, Kapila D. Silva: 24-38. London, New York: Routledge, 2016. P. 24-38.

4 वसन्त महर्जन थप सामग्री. महामारीमा नेवार समाजः उहल्यै पनक्विवारेन्टनि' र 'आइसोलेसन' मा बस्थे ! थप सामग्री [Maharjan B. Newar Society during the Pandemics: They used to maintain quarantine and isolation way back in past too] // Himal Khabar. 2020. Available at: https://www.himalkhabar.com/ news/113918 (accessed: 12.05.2020).

5 Convention for the safeguaring of intangible cultural heritage // UNESCO.2003. Available at: https://ich.unesco.org/en/convention (accessed: 12.05.2020). 
both aspects, can these be negotiated in terms of architecture and planning at multiple scales?)

- Is home defined by just "four walls and roof"? Are there invisible subtle relations between

people and home? What are they?

- Does ICH capture those relationships between people and home?

- Does ICH explain principles of urban planning of our heritage cities?

- Can ICH be a guidance for a better city planning?

We can begin to reflect on these questions from an individual scale, and then move onto communal scale as a city or country. At individual level, perhaps the pandemic made us realise about our own self, but also about our "home". Perhaps many of us may not have spent such an extended time at home. To me, this has been a revealing moment to understand the techniques, the space, some problems and some opportunities that are at my own home - the physical structure and space called home. How far was I engaged with it - even though it is my heritage and I teach about heritage? Does the material makes it "home" or is it the space or is it my attachment that makes it home? Once I answer these set of questions, then I can ask a question to my architectural education, and perhaps the practice of architecture. Do we - as architects, design home as a detached space or do we allow it to have some emotions? Of course, architects alone cannot make a building as a home, it is the users who make it home. Then, how far have we gone to the users (once they occupy the home) and get feedback on our design or design process?

Similarly, if we change the scale to the city, then the question should be "what do the residents think of their cities"? Aren't the migrant labours who occupied different parts of the city for so long have a say on this? Why - in the face of pandemics, none of the migrants were able to feel connected to the city? As I bothered about this from heritage perspective, I wonder whether some of the questions should bother our planners and policy makers and politicians. Today, South Asia is facing another pandemic in the making due to the irresponsiveness of our politicians and policy makers towards these users of the city. Perhaps such is a lesson that this pandemic has brought to professions like architecture and planning, as well as players like politicians and policy makers. How can then heritage offer any insights into such problems? I will briefly touch upon this next.

Other stakeholders of the city aside, it should be the roles of heritage enthusiasts and practitioners and institutions to interpret the heritage in a holistic manner. So far, we only interpret the bricks and the mortar and form and the shape, with less concern about the legacies of who built them. The workers were there when these monuments of the Kathmandu valley were built. The patrons had ensured them of their livelihoods but also necessary social security so that the artisans and artists could perform their best. While we create a thriller by offering anecdotal stories that so and so artist was chopped off of his hands after creating a masterpiece, we conveniently ignore the general practice that the artists and artisans were respected for their skills. Do our cities have similar respect for the millions of workers (mostly the migrant workers in today's societies) who actually built our cities? This may sound an irrelevant argument in today's capitalist society but any serious heritage thinker - who is equally bothered about process as much as she is bothered about a product that exists today as heritage, whether tangible or intangible, shall be able to see the connection I am trying to make here. Heritage is and should be such deep thinking exploring the roots and the recipes of creating such legacies, and NOT just scattered compositions of bricks and mortars and spaces in our cities. Missing that in Kathmandu valley rendered us today devoid of any pre-existing places which would have played the role of a quarantine space (as I mention previously that there used to be quarantine spaces built at main entry points to the valley). What happened to such a wisdom? Though some communities may still follow the rituals associated with such practices, would not it be the role of a heritage thinker and practitioners to connect such rituals with some designated spaces in the fringes of the city, but more importantly to curate such a beautiful 
architectural and planning theory and practice that were in place centuries before today's pandemics?

\section{City it was}

It seems the settlement evolution in the Kathmandu valley had in past put in provisions for the needs like quarantine and isolation (not these words but equivalent words in Newari language), which are still reflected in some of the rituals and traditions that the Newar community follows still today. Perhaps today the rituals are objectified and only symbolic gestures are carried out, hence losing out on the essence of the rituals and practices or perhaps confining the practices in limited sense only to the community and not to the city dwellers as a whole. In past, there seems to have been space and structures allocated for a businessman to quarantine himself while returning from a business trip to Tibet or elsewhere. Maharjan mentions of accounts of missionaries who had noticed that the roads would be blocked whenever there would be fear of any contamination being spread in the then cities $^{6}$.

\section{City as heritage site}

However, the above accounts rarely feature in the narrative of a world heritage that Kathmandu valley proudly boasts of having in its several historic and religious sites. Even the intangible practices of purification and precautions today are considered as unscientific and blind faith, and hence increasingly being not followed. Of course, one can choose to follow a more contemporary processes, but the essence could have been kept alive in spirit so that dealing with pandemics would not be a matter of following government imposed lockdown but something that communities could anticipate and enforce voluntarily. Perhaps the necessary lockdowns could have been a celebratory communal declaration rather than an imposition from the authorities.

\section{City during the COVID-19 crisis}

Today, the reality of these cities are starkly different. Kathmandu valley - a growing urban area today has its history and foundation to multiple layers of built and unbuilt heritage in which taking care of nature and people through rituals and practices that were closely associated with schemas of place, streets and the natural features. An interesting crossroad of the ideals of Hinduism and Buddhism, the valley's heritage is applauded for demonstrating the tenets of compassion and care. The city residents - despite having the heritage of compassion and carefulness, have mostly turned blind to fellow citizens. Take for example - different kinds of guthis (a social institution and practice) in the Kathmandu valley.

Guthis are community institutions which have multiple functions - like a local cooperative group to something like a neighbourhood block group, and better as a public trust that is responsible for building and maintaining public infrastructure including buildings and spaces, as well as maintaining them by using the land trust and other resources associated with the guthis. The guthis concept could have very well offered a huge refuge in the crisis induced by the pandemic as well, but officially the practice of guthi has largely been truncated to only some small family and community guthis, while the bigger ones being integrated into the modern governance system. The ecosystem of land and other resourc-

6 Maharjan B. Newar Society during the Pandemics... 
es that were weaved together through these guthis have long been disrupted, hence the traditional water supply and other water networks, the culture of community-connections, culture of precautionary measures like the cultural process of quarantining oneself if coming from foreign trade and so on, were long lost. Perhaps what drew attention of peoples like Eduard Sekler and Carl Pruscha in the 1970s were the people, culture and their manifestations through the monuments and landscapes of the Kathmandu valley. Such a global attention to Kathmandu valley eventually led to the listing of selected monument zones of Kathmandu valley as the first nomination from South Asia in the UNESCO's world heritage sites list in 1978. However, the limited vision of the nomination dossier or document has never been critically examined or expanded. Instead, it became further narrower as was the boundaries of the world heritage properties in the valley. Any serious heritage professional must profess such a shortcoming in her heritage thinking and practice.

\section{Perspectives from the ICH discourse: $\mathrm{ICH}$ as a source of resilience and recovery}

As a solace to the above concern, it is heartening to note that the agencies and individuals related to the heritage sector have been optimistic about the role of heritage in times of crisis and disasters. This was evident during the COVID-19 pandemic as well through initiatives undertaken by UNESCO, ICCROM, ICOMOS and others. It can generally be inferred that many community groups may find their cultural practices as a refuge during times of crisis. However, many of our cultural practices require a larger gathering, which is not advisable in such situations. It is for such situations that the understanding and safeguarding of $\mathrm{ICH}$ should be updated to fit the changing needs including those of the pandemic response.

In Kathmandu valley, some of the traditional festivals came into dispute in 2020 when the government restricted such practices in view of the pandemic situation. Had there been open-mindedness from both sides and a timely discussion were made feasible, perhaps we could have not disrupted the cultural beliefs while maintaining the health advisories and practices. Perhaps negotiations and revisions to the process could be done to allow important cultural traditions to continue even during the lockdown. In absence of any anticipation of such crisis, there was not enough time and preparation for such timely negotiations and modifications of practices. However, I would also argue that it was also a matter of lack of cultural sensitivity on the part of the government while at the same time lack of a proactive adaptation on the part of community of practitioners. This situation either left traditions halted historically, or led to violent conflict between the practitioners' community and the law-enforcement authorities. But perhaps the law enforcement processes and governance structures should have allowed some space for consideration and opportunities of negotiation with various stakeholders within a city of living heritage to find out appropriate ways to maintain physical distance while pursuing crucial social and cultural functions. Yet, while saying so I am not suggesting to put anyone at risk of infection and health risk. I think the missing component here is our heritage theorization which have largely been busy objectifying and glorifying certain aspects, and not paying enough attention to various everyday aspects and deeper meanings. The agencies sponsoring or promoting various safeguarding measures may consider promoting such alternative practices and frameworks extensively at all times, for example - UNESCO's platoform on living heritage and the COVID-19 pandemic $^{7}$.

7 UNESCO launches platform on living heritage and the COVID-19 pandemic // UNESCO. Available at: https://ich.unesco.org/en/news/unesco-launches-platform-on-living-heritage-and-the-covid-19pandemic-13263 (accessed: 10.05.2020). 


\section{Reflections on broader practices on heritage, architecture and planning}

COVID-19 has exposed the limitations of many of our thinking and practices, at least this is what I observed in the context of South Asian cities where the globally accepted measure of lockdown to prevent the spread of COVID-19 triggered the plight of millions of migrants on the momentarily empty roads and highways for a long-march towards rural and semi-urban segments of countries - not a great example of urban planning, where their "homes" would not be seen as any great example of architecture. Have we missed something in these scenarios? Can a perspective of $\mathrm{ICH}$ help us understand these bitter realities of $21^{\text {st }}$ century? This is where perhaps there is a possibility of examining our built environment through a lens of intangible cultural heritage. In addition, I believe there is a strong need of self-reflection and perhaps a corrective measure in our general heritage practice. Heritage professionals must recognise the pitfall of objectifying the notion of intangible cultural heritage - this may be unintended consequences too. In relation to architecture and building context, intangible cultural heritage are largely perceived as either an add-on to an architectural process (like a building craft or aesthetic and symbolic decorations) or as a performance in a space (as cultural practices that fill up a space). Instead, I argue that the intangible aspects could very well be part of any design intervention or exercise in a given context. Similarly, in urban design or planning processes, intangible cultural heritage could have been a useful reference to conceptualise design and use of spaces, their hierarchies and more importantly bringing in resilience in our urban design.

So, rethinking cities through $\mathrm{ICH}$ requires a few key principles to be born in our mind while we research, design, build and live in a city that is founded on the historic and cultural legacies, but is aiming to be competently comfortable, safe and future-oriented cities. Elaborating on these would be a scope of another paper, but I conclude by highlighting key points to move into that direction:

Layers of Heritage, Knowledge Systems as ICH: Enhanced understanding of Architecture \& Urban Planning, Regional Development. It appears that ICH discourse has also been trapped into an objective discourse, and moving towards monumentalizing of the intangibles and knowledges and practices by adopting a listing process which has the potential to objectify the $\mathrm{ICH}$ like that of the World Heritage list. Instead of a unique or romantic or monumental gesture, ICH needs to be understood as layers of heritage - particularly displayed through the knowledge systems and visible practices and performances (both with physical products or non-physical experience and expressions). If such layers are integrated into the education of architects and urban planners, then perhaps the practices around built environment would have also facilitated the continuation of such $\mathrm{ICH}$ elements in our cities. However, this is not an entirely new argument. Like some thought-processes in the heritage sector itself, the practice of architecture has also embraced similar concepts through socially responsive architecture, culturally sensitive architecture and urban design, environment-behavior design approach, among others. On this, the global proliferation of heritage discourse and set of practice mechanisms should have supplemented for creating synergies for better and livable cities, but the outcomes have not been successful everywhere. It is ironic that the culturally rich contexts are today desperate to ditch their legacies to embrace a universalized design language, thus missing opportunities of creating good architecture and cities anchored on cultural identity and sustainable practices - both in cultural and environmental sense as well as in economic development perspectives. It is where I think perhaps a ready reference to $\mathrm{ICH}$ as a part of culture-sensitive design philosophy may be helpful in nurturing the potential synergy between the design practice and heritage practice.

$\mathrm{ICH}$ is not an "intangible", "invisible" or an "add-on" to the built heritage. In my opinion, one of the sheer flaw in our understanding is to think of ICH as an "invisible", hence at times easy to avoid or ignore. Therefore, we should articulate $\mathrm{ICH}$ for being inseparable part of the tangibles and everyday life emphasizing on inclusivity than invisibility or intangibility. $\mathrm{ICH}$ are 
integral characteristics and elements of many aspects that our cities are built with. ICH is a way of understanding, designing, and functioning of built environment, that interconnects both the "cultural" and "natural" as well as "tangible" and "intangible". ICH is the soul, which architecture and urban planning need to enshrine in design and function.

$\mathrm{ICH}$ as an expression of people's relationship with their homes, neighbourhoods and cities. In continuation of the above arguments, I would like to conclude by pointing out my attempt of answering some of the questions that were raised earlier in this paper, i. e. Does ICH capture those relationships between people and home? Does $\mathrm{ICH}$ explain principles of urban planning of our heritage cities? Can ICH be a guidance for a better city planning?

Let me begin to reflect on these questions by considering a few anecdotal and personal experiences. During this pandemic, as I "stay home" at my family home in Nepal, I realise a few aspects of this home that is missing in other houses that I have considered as home elsewhere. In terms of the spaces, a traditional home in $\mathrm{Nepal}^{8}$ would have a semi-private space that creates a buffer between the public space and private space. Somewhere close to this space would be a water source (either a tap or just some vessels with water) so that family members returning home or visitors could wash their hands and feet before entering the home. The segregation of kitchen and hierarchy of dining spaces as well as some rituals and everyday practice in using these spaces have some protocols that would have made much sense during the health pandemic. These traditional homes, however, lacked a comparable toilet and bath facilities as compared to today's lifestyle a major aspect of improvement in traditional houses in Nepal. There have been decent additions of these facilities in wherever the traditional houses are adapted into contemporary urban living as well. These generic designs would have regional variations relating to specific climate and landscape as well as cultural nuances.

Today, on the other hand, a typical family home being built across Nepal mostly follow universal standards and logic in space and structure. They do not have any traces of these traditional space design concepts. These are mere mimicry of a modern apartment living concept though the services and everyday culture in Nepal at large is yet to be like that of apartment living culture. This is a simple illustration of where a potential reference to intangible cultural heritage could inform architects of space requirement and cultural contexts for a Nepali house. This should not mean to go back into the traditions blindly and freeze the culture and lifestyle. Instead, this approach informed by genuine understanding of ICH could respond to the needs of people in realistic manner by fusing the familiar with the desirable, and integrating the traditional knowledges into the contemporary aspirations. Similar analogy can be drawn to town planning aspects, that can contribute to a balanced urban design and planning strategies.

In rural areas, houses built in synchronisation with agricultural practices not only ensures proper lighting and ventilation for each individual houses, but these became natural way of maintaining distance and "stay home" was not a big issue for rural population during the pandemic. The crowded urban areas in Nepal, had different set of experience where the life style was meant to be an urban one without decent urban services. Hence, what has happened in the built environment in Nepal, is we have left the traditional ways but have not yet learned the essence of modern living that is being blindly copied everywhere. Instead, if we (architects and planners) had attempted for gradual transition by latching onto the traditional ways but slowly and necessarily adapting and improving upon, I am sure the experience of these spaces would have been much more meaningful and timely. Again, the broader definition and everyday perspectives on $\mathrm{ICH}$ could have been a good start in such design thinking.

8 I recognise that I am generalising diverse cultures found within Nepal, but this experience is not unique to me, hence I decide to call it as a "Nepali family" in generic sense. 
As per its definition, $\mathrm{ICH}$ can be understood in multiple but overlapping ways as connected to homes and neighbourhoods as well as cities. Not only it captures the meaning of spaces, value and hierarchies of the use of spaces and importance given to them, but ICH is also about the processes of creating such spaces including built structures and natural landscapes. Further, ICH includes traditions and practices which are weaved intricately around the built environment that is designed with certain anchoring concepts (which is what the previous sentence captured). The safeguarding of $\mathrm{ICH}$ is about documenting and continuing these elements of $\mathrm{ICH}$, hence it clearly makes sense for us to agree that there is a great potential of integrating $\mathrm{ICH}$ as a concept and practice tool in design thinking and practice - particularly related to our built environment. Let me elaborate this by referring back to the example of Kathmandu valley that I used in this paper.

There are myths about how the valley was founded as a way of making it a habitable land out of a pond in the ancient times. Archaeologically proven ancient settlement patterns attest the planning concept adopted by which the agricultural land were preserved while setting up settlements at higher lands. Similarly the water resources and forest resources as well as key entry points were designated and integrated into the then planning process by way of introducing varieties of sacred spots and shrines which were connected to people through numerous festivals and rituals, and so on. These are all well documented, and many of them are still practiced today. Had the planners and developers paid attention to any of these, we would not have seen drying of water resources, disruption of water supply through traditional water canal systems, and maintaining of various other aspects of natural and cultural resources management. I would not like to end my critique just with reference to the development professionals, planners and governments. In fact, the communities themselves have ditched their $\mathrm{ICH}$ for the want of a rapid modernisation. It is where the professionals input should have come handy. But what have heritage professionals and institutions done?

Kathmandu valley was one of the first listed world heritage sites from the region, but objectifying the notion of heritage (both in the national policy via the Ancient Monuments Protection Act and the jurisdiction of the Department of Archaeology) and internationally through the World Heritage listing, the achievement of the last six decades of modernisation has uprooted the desire of progress from the bedrock of cultural heritage. The streets that were meant for pedestrians and cultural processions almost every other day have been universally widened to make them "car-friendly" but ignoring the traditional hierarchy of spaces. Agricultural lands have been blindly approved for "land pooling" schemes without much consideration for open spaces - let alone agricultural purpose. In the name of modernisation, traditional community institutions like guthi are largely made dysfunctional by bringing them under the act with the same name. I have demonstrated elsewhere that the mandate of preserving heritage legacies in Kathmandu valley could have been achieved by integrating the guthi system into modern heritage laws and frameworks $^{9}$. However, these mega-flaws are as much to be blamed on the politicians as much to the heritage fraternity. If the very idea of heritage would not have been limited just to the monumental and the things of the past, we would have perhaps seen the relevance of living heritage that exists in the everyday life. This could have given useful glimpse into what contemporary architecture and urban design should aim for. We can only hope and pledge now that the pandemic - in its truly historic experience, has awakened us up to rethink heritage, and re-orient our practices. Unless the heritage custodians, practitioners and

9 Chapagain N.K. Towards a framework for applicability and adaptability of traditional knowledge systems and modern knowledge systems: case studies from Nepal // Traditional Knowledge Systems and the conservation and management of Asia's heritage / eds Gamini Wijesuriya, Sarah Court. ICCROM, 2020. P. 211-223. 
professionals reflect on their own practices and rethink the frameworks for heritage practice in a critical manner, we will not be able to position the cultural heritage as a pillar for sustainable development. This is more so important in the context of ongoing discussion on achieving the sustainable development goals ${ }^{10}$ by 2030 - particularly the goal number 11 and target 11.4 which uses the term heritage - both natural and cultural (assuming that the cultural does mean the broader intangible cultural heritage as well).

\title{
References
}

Chapagain, Neel Kamal. 2016. Blurring boundaries and moving beyond the tangible/intangible and the natural/cultural classifications of heritage: Cases from Nepal. Cultural landscapes of South Asia: Studies in heritage conservation and management, eds Amita Sinha, Kapila D. Silva: 2438. London, New York, Routledge.

Chapagain, Neel Kamal. 2020. Towards a framework for applicability and adaptability of traditional knowledge systems and modern knowledge systems: case studies from Nepal. Traditional Knowledge Systems and the conservation and management of Asia's heritage, eds Gamini Wijesuriya, Sarah Court, 211-223. ICCROM.

Gautam, Abhushan. 2020. When the air is clean. Nepali Times. 15 May 2020. Available at: https:// www.nepalitimes.com/banner/when-the-air-is-clean (accessed: 16.05. 2020).

Maharjan, Basanta. 2020. Mahamarimaa Newar Samaj. Uhile pani quarantine ra isolation maa basthe re! [Newar Society during the Pandemics: They used to maintain quarantine and isolation way back in past too]. Himal Khabar. 11 May 2020. Available at: https://www.himalkhabar. com/news/113918 (accessed: 12.05.2020). (In Nepali)

Smith, Laurajane. 2006. Uses of heritage. London, Routledge.

Received: October 6, 2020

Accepted: December 23, 2020

\section{Нематериальное культурное наследие в архитектуре и градостроительстве}

Н. К. Чапагэйн

Для цитирования: Chapagain, Neel Kamal. Intangible Cultural Heritage in architecture and urban planning // Правоведение. 2020. Т. 64, № 1. С. 35-46.

https://doi.org/10.21638/spbu25.2020.103

\begin{abstract}
Статья отражает некоторые наблюдения за городами во время пандемии COVID-19 особенно во время их первоначального полного блокирования, которое большинство стран испытали с марта 2020 г. Одним из последствий COVID-19 стала вынужденная привязка людей к своим домам, где бы они ни находились. До этого многие редко задумывались о собственном жилище, постоянном или временном, и его архитектуре. Пандемия дала возможность осмыслить архитектуру и городское планирование в очень личном масштабе - от комнаты, квартиры или дома до района, а затем в некоторой степени и города. Наступил интересный исторический момент, позволивший задуматься об архитектуре и пространстве, а также о том, как они проектируются и планируются. COVID-19 выявил ограниченность многих мыслей и практик. Автор статьи размышляет о собственном опыте пребывания в доме, а также осмысляет наблюдения за окраинами южноазиатских городов, где общепринятые меры изоляции для предотвращения распространения COVID-19 вызвали тяжелое положение миллионов мигрантов, вынужденных перемещаться на большие расстояния по временно пустым дорогам и магистралям, ведущим в сельские и полугородские сегменты стран. Автор пересматривает свое
\end{abstract}

10 Sustainable Development Goals // United Nations. Available at: https://sdgs.un.org/goals (accessed: 10.05 .2020 ). 
понимание архитектуры и планирования в городском контексте, используя понятие нематериального культурного наследия (Intangible Cultural Heritage, ICH), поддержанное Конвенцией ЮНЕСКО 2003 г., выясняет, может ли концепция ICH предложить полезные идеи для достижения лучших результатов в современном архитектурном и градостроительном мышлении и практике, а также размышляет, способна ли перспектива ICH помочь понять горькие реалии XXI в.

Ключевые слова: COVID-19, нематериальное культурное наследие, Долина Катманду, Всемирное наследие, Архитектура и городское планирование, ЮНЕСКО.

Статья поступила в редакцию: 6 октября 2020 г. Рекомендована в печать: 23 декабря 2020 г.

Чапагэйн Нил Камал - доктор философии, независимый архитектор и специалист по наследию, Непал, адъюнкт-профессор, директор, Центр управления наследием Ахмедабадского университета, Университет Ахмедабад, Индия, 380009, Гуджарат, Наврангпуры, Ахмедабад, Центр Шесть Дорог; neel.kamal@ahduni.edu.in 